\title{
SCREENING OF SOME FERMENTED MILK FOR DECARBOXYLASE AND BIOGENIC AMINES PRODUCING MICROORGANISMS AND THEIR PUBLIC HEALTH SIGNIFICANCE
}

\author{
JEHAN ISMAIL IBRAHIM \\ Department of Food Hygiene and Control, Faculty of Veterinary Medicine, Suez Canal University, Ismailia, Egypt
}

Received: 29 February 2016; Accepted: 15 March 2016

\begin{abstract}
The objectives of this study were based on screening for presence of decarboxylase producing microorganisms (Enterobacteriaceae, Enterococci and Lactobacilli) in sour milk, yoghurt and labenh, collected from supermarkets in Ismailia City. The isolated strains were tested for decarboxylase activity and the levels of histamine, tyramine, putrescine and cadaverine were determined in the examined samples. The results revealed that all the examined samples were contaminated with Enterobacteriaceae and Enterococci at variable counts. All the isolated strains of Enterobacteriaceae, Enterococci and Lactobacillus spp. have the potential to release decarboxylase enzymes with biogenic amines formation. The examined samples were found to contain the estimated amines with variable levels, expect yoghurt that didn't contain tyramine. In conclusion, there was a positive correlation between the type of microorganisms present in fermented milk and the type of biogenic amines formed. The prevention of biogenic amines formation in fermented milks could be achieved by following good hygienic measures and careful screening of lactic acid bacteria for amino acid decarboxylase activity before selecting as starter or probiotic strains in dairy industry.
\end{abstract}

Key words: Decarboxylase bacteria, fermented milk, biogenic amines

\section{INTRODUCTION}

Fermented milk products such as buttermilk, sour cream, yoghurt, sour milk and labenh are popular dairy products. The high nutritive value of the fermented milk, its attractive taste and extended shelf-life at low temperature and $\mathrm{pH}$ which reduce the multiplication of pathogenic microorganisms makes it a valuable food (Costa et al., 2015). The addition of probiotics to these products increases their potential functional benefits with health, as they produce substances benefit for human health. However, other kinds of metabolites, such as biogenic amines may also be produced by starter culture and probiotic strains in fermented milk (Kongo et al., 2006).

Biogenic amines can be formed in food primarily due to the release of specific amino acids and by the action of decarboxylases enzymes produced by certain microorganisms such as Enterobacteriaceae and Enterococci (Priyadarshani and Rakshit, 2011).

Corresponding author: Dr. JEHAN ISMAIL IBRAHIM E-mail address: jehanismail14@yahoo.com

Present address: Department of Food Hygiene and Control, Faculty of Veterinary Medicine, Suez Canal University, Ismailia, Egypt
The production property and storage period of fermented milk help the formation of biogenic amines by enhancing the activity of proteolytic microorganisms that increases the amount of free amino acids (Linares et al., 2011). The levels of existence of biogenic amines are related to numerous factors, such as the composition and availability of free amino acids, water activity, storage time, storage temperature, $\mathrm{pH}$ of the product and the presence of decarboxylase-positive microorganisms. The $\mathrm{pH}$ is consider an important factor for fermentation and formation of biogenic amines. The amino acid decarboxylase enzyme is highly active in an acidic environment, with optimum $\mathrm{pH}$ around 5.0 (Schirone et al., 2012). Ingestion of foods containing high levels of tyramine and histamine causes numerous outbreaks of food intoxication because they have vasoactive, psychoactive and toxicological properties. In addition, putrescine and cadaverine may potentiate the toxicity of these biogenic amines (Ôzdestan and üren, 2010). Therefore, this study aimed to isolate and identify the decarboxylase producing microorganisms, and to determine their ability to release decarboxylase enzymes. Also, the levels of the most prevalent biogenic amines such as histamine, tyramine, putrescine and cadaverine in the fermented milk samples were estimated. 


\section{MATERIALS AND METHODS}

Collection of samples

A total of 45 samples (15 each) of sour milk, yoghurt and labenh were collected from supermarkets in Ismailia City, Egypt. The samples were transported promptly in an ice-box to the laboratory for microbial and biogenic amines estimation.

\section{Microbiological and decarboxylase assessment}

Enterobacteriaceae was enumerated using violet red bile glucose agar (OXOID) (Kornacki and Johnson, 2001). Enterococci count was performed using Kanamycin Escculin Azide agar (OXOID) according to Hartman et al. (2001). The isolated strains were identified in accordance with the protocol followed by Manero and Blanch (1999). Lactobacilli were isolated using DEMAN Rogosa Sharpe agar (MRS) (HiMedia) according to Gupta et al. (1996).

The identified Enterobacteriaceae and Enterococci strains were screened for decarboxylase activity using improved screening medium according to Joosten and Northolt (1989). The lactobacillus spp. were estimated for decarboxylase activity using MRS agar according to Bover-cid and Holzapfel (1999).

\section{Biogenic amines assay}

Twenty-five grams of homogenized samples were used for extraction of biogenic amines using the method of Antila et al. (1984). The standard amines, histamine- $2 \mathrm{HCl}$, tyramine- $2 \mathrm{HCl}$, putrescine- $2 \mathrm{HCl}$ and cadaverine-2 $\mathrm{HCl}$ were prepared using dansylchloride (Sigma) according to the method described by Antila et al. (1984). Ten $\mu$ l of each sample extract were spotted onto thin layer chromatography plates (TLC) (Aluminum foil 20x20 $\mathrm{cm}$ coated with silica gel $\mathrm{G}$ 60) and after being developed in chloroform: benzene: triethylamine (6: 4.5: 1) for $17 \mathrm{~cm}$ heights, then dried. The resulted zones were examined and marked under long ultraviolet wavelength $(360 \mathrm{~nm})$. The marked areas were determined using CS-9000 dual wavelength flying spot scanning densitometer (SHIMADZU) using wavelength $254 \mathrm{~nm}$. Standard curve of each dansylamine (standard amine) was used in the calculation of the concentration of biogenic amines expressed as $\mathrm{mg} / 100 \mathrm{~g}$ in the examined samples according to Ayesh et al. (1995).

\section{Statistical analysis}

Data were analyzed using the two-ways analysis of variance (ANOVA) according to the general linear model procedures. Logarithmic transformations were applied for all microbiological counts. Mean separations were done through Duncan's Multiple Range Test using the Statistical Analysis System, SAS 9.2, (SAS Institute Inc., 2009). Results were considered statistically significant at $(P \leq 0.05)$.

\section{RESULTS}

Table 1: Logarithmic counts of Enterobacteriaceae and Enterococci in examined samples

Mean (Logarithmic) $\pm \mathrm{SE}$

\begin{tabular}{llll}
\cline { 3 - 4 } Microorganisms & & & $P$-value \\
& Sour milk & Yoghurt & Labenh
\end{tabular}

$\begin{array}{lllll}\text { Enterobacteriaceae } & 3.74443^{\mathrm{b}} \pm 0.13 & 3.63357^{\mathrm{b}} \pm 0.26 & 4.82556^{\mathrm{a}} \pm 0.12 & 0.001\end{array}$
Enterococci
$4.19515^{\mathrm{b}} \pm 0.13$
$3.59511^{\mathrm{c}} \pm 0.19$
$5.13021^{\mathrm{a}} \pm 0.11$
0.001

*Log counts with different superscripts showed significant differences at $P \leq 0.05$.

*The original counts can be obtained by the antilogarithm (Base 10) of these results. 
Table 2: Decarboxylase enzyme producing isolates in the examined samples

\begin{tabular}{|c|c|c|c|c|c|c|}
\hline \multirow{2}{*}{ Isolates } & \multicolumn{2}{|c|}{ Sour milk } & \multicolumn{2}{|c|}{ Yoghurt } & \multicolumn{2}{|c|}{ Labenh } \\
\hline & No. & $\%$ & No. & $\%$ & No. & $\%$ \\
\hline \multicolumn{7}{|l|}{ Enterobacteriaceae spp. } \\
\hline E.coli & 8 & 100 & 13 & 100 & 9 & 100 \\
\hline Enterobacter aerogenes & 7 & 100 & 3 & 100 & 5 & 100 \\
\hline Citrobacter diversus & 3 & 100 & 0 & 100 & 0 & 100 \\
\hline Proteus vulgaris & 4 & 100 & 2 & 100 & 3 & 100 \\
\hline Klebsiella pnrumoniae & 3 & 100 & - & - & 1 & 100 \\
\hline \multicolumn{7}{|l|}{ Enterococci spp. } \\
\hline E.fecalis & 12 & 100 & 15 & 100 & 11 & 100 \\
\hline E.faecium & 3 & 100 & - & - & 4 & 100 \\
\hline *Lactobacillus spp. & 15 & 100 & 15 & 100 & 15 & 100 \\
\hline
\end{tabular}

Table 3: Biogenic amines levels $(\mathrm{mg} / 100 \mathrm{~g})$ in examined samples

\begin{tabular}{ccccc}
\hline \multirow{2}{*}{ Type of Amine } & Sour milk & Yoghurt & Labenh & \multirow{2}{*}{ P-value } \\
\cline { 2 - 4 } Histamine & Mean \pm SE & Mean \pm SE & Mean \pm SE & 0.034 \\
\hline Tyramine & $0.97^{\mathrm{a}} \pm 0.13$ & $0.56^{\mathrm{b}} \pm 0.11$ & $1.19^{\mathrm{a}} \pm 0.12$ & 0.001 \\
\hline Putrescine & $1.38^{\mathrm{a}} \pm 0.19$ & $0.000^{\mathrm{c}}$ & $2.28^{\mathrm{b}} \pm 0.13$ & 0.001 \\
\hline Cadaverine & $0.92^{\mathrm{a}} \pm 0.21$ & $0.02^{\mathrm{c}} \pm 0.004$ & $1.51^{\mathrm{b}} \pm 0.10$ & 0.001 \\
\hline
\end{tabular}

*Different superscripts showed significant differences at $P \leq 0.05$.

Table 4: Correlations between counts of microbial groups and the type of biogenic amines

\begin{tabular}{lcc} 
& $\begin{array}{c}\text { Type of } \\
\text { biogenic amines }\end{array}$ & \multicolumn{2}{c}{ Microbial groups } \\
\cline { 2 - 3 } Histamine & Enterobacteriaceae & Enterococci \\
\hline Tyramine & $0.53^{* *}$ & 0.23 \\
\hline Putrescine & -0.04 & $0.31^{*}$ \\
\hline Cadaverine & 0.22 & 0.06 \\
\hline
\end{tabular}

-The range $< \pm 0.5$ indicates weak correlation

-The range $>0.5$ indicates strong correlation

-1.0 indicates perfect correlation

* Correlation is significant at the 0.05 level $P \leq 0.05$.

** Correlation is highly significant at the 0.01 level $P \leq 0.01$. 


\section{DISCUSSION}

The ability of microorganisms to form biogenic amines was considered as strain specific property rather than a species related property. Amine formation was recognized as a defense mechanism of microorganisms against an acidic environment. Moreover, some strains with decarboxylase activity could overcome or reduce the effects of temperature, sodium chloride and other biological and chemicophysical factors that induce stress responses in the bacterial cells by the production of some biogenic amines (Karovičová and Kohajdov, 2005).

Data illustrated in the Table 1 revealed that all the examined samples contained Enterobacteriaceae and enterococci at variable counts. The highest bacterial counts were recorded in labenh, sour milk and yoghurt, consequently. All bacterial strains of Enterobacteriaceae, enterococci and Lactobacillus spp. isolated from the fermented milk samples had the ability to release decarboxylase enzymes with biogenic amines formation (Table 2). These results were consistent with Calles-Enríquez et al. (2010) and La Gioia et al. (2011) who reported the presence of tyrosine and histamine decarboxylase activity in strains from various starter cultures. Priyadarshani and Rakshit (2011) suggested that amine formation by starter culture is strain dependent and not related to the species in which Lactobacillus casei and Lactobacillus delbrueckii subsp. bulgaricus were found to produce biogenic amines. While, biogenic amines formation was not released by Lactobacillus acidophilus, Lactobacillus lactis subsp. Lactis, Lactococcus lactis subsp. lactis and Lactobacillus plantarum strains.

Concerning the concentration of biogenic amines, high level of histamine was detected in labenh and sour milk then yoghurt, consequently. There was a significant difference of the levels of histamine between sour milk and yoghurt, as well as between labenh and yoghurt (Table 3). Costa et al. (2015) detected histamine in fermented cow's milk (average $1.79 \mathrm{mg} / 100 \mathrm{~g}$ ) and in fermented goat's milk (average $5.3 \mathrm{mg} / 100 \mathrm{~g})$. On the other hand, lower histamine concentration (average $0.31 \mathrm{mg} / 100 \mathrm{~g}$ ) was detected in sour milk that previously reported by Magwamba et al. (2010). Bodmer et al. (1999) reported higher level of histamine with a mean value of $1.3 \mathrm{mg} / 100 \mathrm{~g}$ in yoghurt. Sömer and Kılıç (2012) couldn't detect histamine in any of the examined labenh samples. The presence of histamine in food represents public health significant and has physiological and toxicological effects. Parente et al. (2001) reported that histamine intake in a level of $40-100 \mathrm{mg}$ and higher than $100 \mathrm{mg}$ causes intermediate and intensive poisoning, respectively. Moreover, Histamine poisoning occurs after the consumption of food containing biogenic amines at concentrations higher than $500 \mathrm{ppm}$ and manifests by an allergic reaction
(Gonzaga et al., 2009). Yongmei et al. (2009) added that the predisposing factors of histamine poisoning are people having deficient in natural mechanisms for detoxifying biogenic amines through genetic reasons or through inhibition by the intake of antidepressant medicines, such as monoamine oxidase inhibitors (MAOIs).

Regarding tyramine, it was prevalent in labenh (average $2.28 \pm 0.13 \mathrm{mg} / 100 \mathrm{~g}$ ), followed by sour milk (average $1.38 \pm 0.19 \mathrm{mg} / 100 \mathrm{~g}$ ), whereas tyramine didn't detected in yoghurt samples. There was a high significant difference $(P>0.001)$ in levels among all fermented milk products examined (Table 3). Costa et al. (2015) estimated higher results ( 24.5 and $33.3 \mathrm{mg} / 100 \mathrm{~g}$ ) in sour cow's and goat's milks, respectively. On contrary, Sömer and Kılıç (2012) found that none of the examined labenh samples contained tyramine. Tyramine usually formed in fermented dairy products from free amino acid tyrosine, which is further decarboxylated by lactic acid bacteria. It was considered as initiator of dietary induced migraine and hypertensive crisis. Levels of 100-800 mg tyramine have been reported as toxic doses in food similar in symptoms to histamine poisoning (Silla-Santos, 1996; Ôzdestan and üren, 2010).

Putrescin and cadaverine were detected in higher levels in labenh, followed by sour milk then yoghurt. There was a high significant difference $(P>0.001)$ in Putrescin and cadaverine levels among all fermented milk products examined (Table 3 ). Higher levels of putrescine $(3 \mathrm{mg} / 100 \mathrm{~g})$ were detected in yoghurt by Eliassen et al. (2002). However, Sömer and Kılıç (2012) couldn't detect these amines in all labenh samples examined.

Tyramine and putrescine are vasoactive amines that increase blood pressure leading to heart failure or brain hemorrhage. Presence of putrescine and cadaverine, at high concentrations enhances the toxicity of histamine through the inhibition of histamine oxidizing enzymes (Emborg et al., 2005). Different studies revealed that some strains of lactobacilli and $S$. thermophilus can produce cadaverine in dairy products (Gezginc et al., 2013).

There was a highly significant positive correlation $(P$ $\leq 0.01$ ) between histamine and Enterobacteriaceae, as well as a significant positive correlation $(P \leq 0.05)$ between tyramine and enterococci (Table 4). Enterobacteriaceae and enterococci were found to be active in formation of biogenic amines. These results were supported by Marino et al. (2000), who reported that Gram-negative bacteria, mainly Enterobacteriaceae were able to produce histamine, putrescine and cadaverine. Also, Bover-Cid et al. (2001) stated that enterococci were considered as an important tyramine producer in association with fermented foods. The presence of biogenic amines in 
foods has traditionally been used as an indicator of undesired microbial activity. High levels of certain amines have also been reported to indicate the deterioration of food products and/or their defective manufacture (Fernández et al., 2007).

It's clearly evident from the obtained results that despite short storage period of fermented milks, it was found to contain biogenic amines at variable levels that may constitute a public health hazards. In addition, there was a correlation between the type of microorganisms and biogenic amines formation. Therefore, the prevention of biogenic amines formation in fermented milks could be achieved by using temperature control, high-quality raw material, good manufacturing and hygienic practices with careful screening of lactic acid bacteria for amino acid decarboxylase activity before selecting as starter or probiotic strains in dairy industry.

\section{REFERENCES}

Antila, P.; Antila, V.; Mattila, J. and Hakkarainen, $H$. (1984): Biogenic amine in cheese. II. Factors influencing the formation of biogenic amines, with particular reference to the quality of the milk used in cheese making. Milchwissenschaft 39(7): 400-404.

Ayesh, A.M.; Amra, H.A.; Abou-Arab, A.A.K. and Naguib, K. (1995): Detection and determination of eight biogenic amines in frozen mackerel (Scomberomorous spp.) and Sardine (Sardinella spp.) using HPLC. Journal of the Egyptian German Society of Zoology 17(A): 121-135.

Bodmer, S.; Imark, C. and Kneubïhl, M. (1999): Biogenic amines in foods: Histamine and food processing. Inflammation Research 48(6): 296-300.

Bover-cid, S. and Holzapfel, W.H. (1999): Improved screening procedure for biogenic amine production by lactic acid bacteria. International Journal of Food Microbiology 53(1): 33-41.

Bover-Cid, S.; Izquierdo-Pulido, M. and VidalCarou, M.C. (2001): Effect of the interaction between a low tyramine- producing Lactobacillus and proteolytic staphylococci on biogenic amine production during ripening and storage of dry sausage. International Journal of Food Microbiology 65(1-2): 113-125.

Calles-Enríquez, M.; Eriksen, B.H.; Andersen, P.S.; Rattray, F.P.; Johansen, A.H.; Fernández, M.; Ladero, V. and Álvarez, M.A. (2010): Sequencing and transcriptional analysis of the Streptococcus thermophilus histamine biosynthesis gene cluster: factors that affect differential hdcA expression. Applied and Environmental Microbiology 76(18): 62316238.
Costa, M.P.; Balthazar, C.F.; Rodrigues, B.L.; Lazaro, C.A.; Silva, A.C.; Cruz, A.G. and Conte Junior, C.A. (2015): Determination of biogenic amines by high-performance liquid chromatography (HPLC-DAD) in probiotic cow's and goat's fermented milks and acceptance. Food Science and Nutrition 3(3):172-178.

Eliassen, K.A.; Reistad, R.; Risoen, U. and Ronning, H.F. (2002): Dietary polyamines. Food Chemistry 78: 273-280.

Emborg, J.; Laursen, B.G. and Dalgaard, P. (2005): Significant histamine formation in tuna (Thunnus albacares) at $-2^{\circ} \mathrm{C}-$ effect of vacuum- and modified atmosphere-packaging on psychro-tolerant bacteria. International Journal of Food Microbiology 10(3): 263-279.

Fernández, M.; Linares, D.M.; Del Río, B.; Ladero, $V$. and Álvarez, M.A. (2007): HPLC quantification of biogenic amines in cheeses: correlation with PCR-detection of tyramineproducing microorganism. The Journal of Dairy Research 74(3): 276-282.

Gezginc, Y.; Akyol, I.; Kuley, E. and Ozogul, F. (2013): Biogenic amines formation in Streptococcus thermophilus isolated from home-made natural yogurt. Food Chemistry 138(1): 655-662.

Gonzaga, V.E.; Lescano, A.G.; Huamán, A.A.; Salmón-Mulanovich, G. and Blazes, D.L. (2009): Histamine levels in fish from markets in Lima, Perú. Journal of Food Protection 72(5): 1112-1115.

Gupta, P.K.; Mital, B.K. and Garg, S.K. (1996): Characterization of Lactobacillus acidophilus strains for use as dietary adjunct. International Journal of Food Microbiology 29: 105-109.

Hartman, P.A.; Deibel, R.H. and Sieverding, L.M. (2001): Enterococci, In Downes, F.P. and Ito, K. (Eds), Compendium of Methods for the Microbiological Examination of Foods $4^{\text {th }}$ ed. American Public Health Association, p. 83-87. Washington, D.C.

Joosten, H.M. and Northold, M.D. (1989): Detection, growth, and amine- producing capacity of lactobacilli in cheese. Applied and Environmental Microbiology 55(9): 23562359.

Karovičová, J. and Kohajdová, Z. (2005): Biogenic amines in food. Chemical Papers 59(1): 70-79.

Kongo, J.M.; Gomes, A.M. and Malcata, F.X. (2006): Manufacturing of fermented goat milk with a mixed starter culture of Bifidobacterium animalis and Lactobacillus acidophilus in a controlled bioreactor. Letters in Applied Microbiology 42(6): 595-599.

Kornacki, J.L. and Johnson, J. (2001): Enterobacteriaceae, Coliformis and Escherichia coli as quality and safety indicators. In Downes, F.P. and Ito, K. (Eds), 
Compendium of Methods for the Microbiological Examination of Foods $4^{\text {th }}$ ed. American Public Health Association, p. 69-82. Washington, D.C.

La Gioia, F.; Rizzotti, L.; Rossi, F.; Gardini, F.; Tabanelli, G. and Torriani, S. (2011): Identification of a tyrosine decarboxylase gene (tdcA) in Streptococcus thermophilus 1TT45 and analysis of its expression and tyramine production in milk. Applied and Environmental Microbiology 77(3): 1140 1144.

Linares, D.M.; Martín, M.C.; Ladero, V.; Alvarez, M.A. and Fernández, M. (2011): Biogenic amines in dairy products. Critical Reviews in Food Science and Nutrition 51(7): 691-703.

Magwamba, C.; Matsheka, M.I.; Mpuchane, S. and Gashe, B.A. (2010): Detection and quantification of biogenic amines in fermented food products sold in Botswana. Journal of Food Protection 73(9): 1703-1708.

Manero, A. and Blanch, A.R. (1999): Identification of Enterococcus spp. with a Biochemical Key. Applied and Environmental Microbiology 65(10): 4425-4430.

Marino, M.; Maifreni, M.; Moret, S. and Rondinini, $G$. (2000): The capacity of Enterobacteriaceae species to produce biogenic amines in cheese. Letters in Applied Microbiology 31(2): 169173.

Ôzdestan, O. and üren, A. (2010): Biogenic amine content of kefir: a fermented dairy product. European Food Research and Technology 231: 101-107.
Parente, E.; Matuscelli, M.; Gadrini, F.; Grieco, S.; Crudele, M.A. and Suzzi, G. (2001): Evolution of microbial populations and biogenic amines production in dry sausages produced in southern Italy. Journal of Applied Microbiology 90(6): 882-891.

Priyadarshani, W.M.D. and Rakshit, S.K. (2011): Screening selected strains of probiotic lactic acid bacteria for their ability to produce biogenic amines (histamine and tyramine). International Journal of Food Science and Technology 46: 2062-2069.

SAS Institute. (2009): Base SAS 9.2 procedures guide. Cary, NC: SAS Institute, Inc. Retrieved March 10, 2010, from the SAS product Documentation web.

Schirone, M.; Tofalo, R.; Visciano, P.; Corsetti, A. and Suzzi, G. (2012): Biogenic amines in Italian Pecorino cheese. Frontiers in Microbiology 3: 171.

Silla Santos, M.H. (1996): Biogenic amines: their importance in foods. International Journal of Food Microbiology 29(2-3): 213-231.

Sömer, V.F. and Kılıç, G.B. (2012): Microbiological, physicochemical properties and biogenic amine contents of the strained yoghurts from Turkish local markets. African Journal of Biotechnology 11(78): 14338-14343.

Yongmei, L.; Xiaohong, C.; Mei, J.; Xin, L.; Rahman, N.; Mingsheng, D. and Yan, G. (2009): Biogenic amines in Chinese soy sauce. Food Control 20(6): 593-597.

\section{فحص بعض الألبان المتخمرة للميكروبات المفرزة لأنزيم الديكربوكسيلاز والأمينات الحيوية وأهميتهم الصحية}

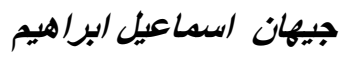

E-mail: jehanismail14@yahoo.com Assiut University web-site: www.aun.edu.eg

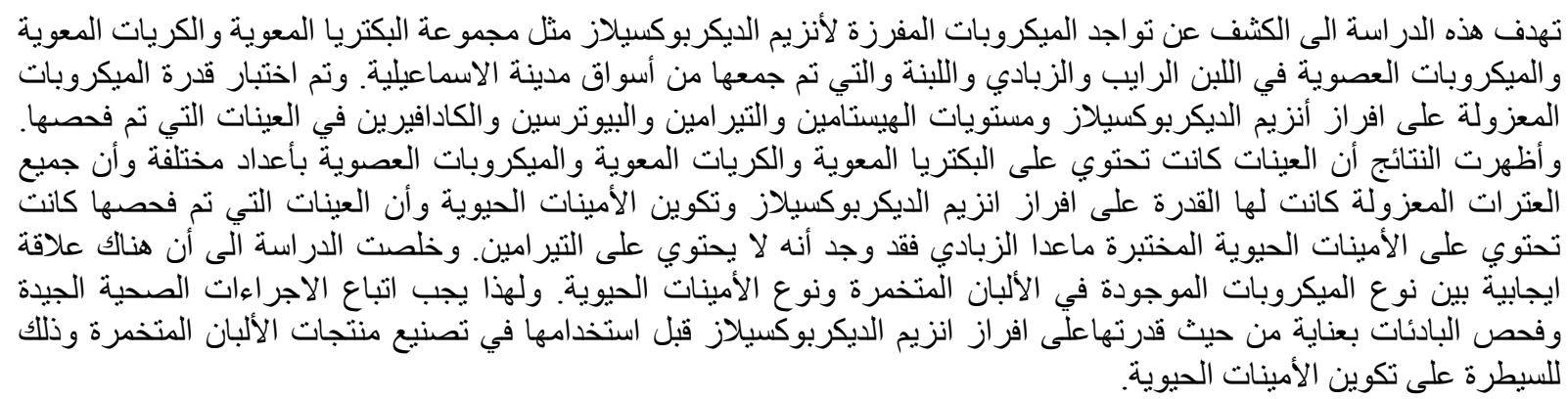

